\title{
Roles of toll-like receptors: From inflammation to lung cancer progression (Review)
}

\author{
JINJING GU ${ }^{1 *}$, YI LIU $^{1 *}$, BIN XIE $2^{*}$, PINGPING YE ${ }^{1}$, JIEFAN HUANG $^{1}$ and ZHE LU ${ }^{1}$ \\ Schools of ${ }^{1}$ Medicine and ${ }^{2}$ Science, Hangzhou Normal University, Hangzhou, Zhejiang 310016, P.R. China
}

Received October 23, 2017; Accepted December 12, 2017

DOI: 10.3892/br.2017.1034

\begin{abstract}
Lung cancer is among the most common malignant tumors worldwide, and is characterized by a low survival rate compared with other cancers. Toll-like receptors (TLRs) are highly conserved in evolution and widely expressed on immune cells, where they serve an important role in the innate immune system by evoking inflammatory responses. Evasion of immune destruction is an important hallmark in the development of cancer. There is an established association between chronic inflammation and cancer, with TLRs serving important roles in the immune response against tumor cells. Recently, TLRs have been identified on tumor cells, where their activation may orchestrate the downstream signaling pathways that serve crucial functions in tumorigenesis and tumor progression. The present review summarizes the roles of TLRs as sensors on lung cancer cells that regulate lung cancer progression with regard to cell growth and invasion, angiogenesis and cancer stem cell behavior. This aimed to provide theoretical support for the development of therapies that target TLR signaling pathways for the treatment of lung cancer.
\end{abstract}

\section{Contents}

1. Introduction

2. TLRs

3. Relationship between TLRs and lung cancer

4. Conclusion

Correspondence to: Dr Zhe Lu, School of Medicine, Hangzhou Normal University, 16th Xuelin Street, Hangzhou, Zhejiang 310016, P.R. China

E-mail: zhelu84@126.com

*Contributed equally

Key words: toll-like receptors, lung cancer, growth, angiogenesis, invasion, cancer stem cells

\section{Introduction}

Lung cancer is among the most malignant tumors worldwide, and in 2012 was reported as the leading cause of cancer-related mortality in men and the second leading cause of cancer-related mortality in women (1). However, there remains to be a lack of effective treatments at present. Lung cancer has a number of subtypes, with approximately $80 \%$ of cases belonging to the non-small cell lung cancer (NSCLC) subtype (2). It is reported that $70 \%$ of patients are diagnosed with lung cancer at a medium or late stage, which makes treatment more difficult (2). Improved prognosis may be achieved if the lung cancer is identified at an earlier stage. Major risk factors of lung cancer include increasing age, air pollution and smoking (2). The Globocan 2012 cancer report by the International Agency for Research on Cancer identified that 1.8 million new lung cancer cases and 1.6 million lung cancer fatalities occurred in 2012 worldwide, accounting for approximately $19 \%$ of all cancer-related mortalities $(1,3)$. In addition to the high rates of morbidity and mortality, lung cancers are also associated with poor prognosis, with the overall five-year survival rate being less than $17 \%$ (4). These data demonstrate the need for more effective strategies for the prevention and treatment of lung cancer.

Inflammation, as a crucial biological response to infection and damage, may also cause damage to the body, and persistent inflammation has been identified to be associated with cancer formation (5). Toll-like receptors (TLRs) recognize structurally conserved molecules derived from microbes (6). Upon binding to cognate ligands, TLRs activate downstream signaling pathways that orchestrate inflammatory responses (6). To date, there have been a number of studies on TLRs regarding their potential role in connecting inflammation and lung cancer (7-9); however, information on their exact roles in lung cancer cells, as well as the underlying mechanisms, remains limited. The present review summarizes the roles of TLRs in lung cancer progression with regard to cell growth and invasion, angiogenesis and cancer stem cells (CSCs), with the aim of providing novel insight on targets for the early diagnosis and treatment of lung cancer.

\section{TLRs}

TLRs are pattern recognition receptors that recognize both pathogen-associated molecular patterns (PAMPs) and damage-associated molecular patterns (DAMPs) (10). TLRs 
are type I single membrane-spanning glycoproteins with an extracellular domain and an intracellular domain. The extracellular domain contains leucine-rich repeat motifs while the intracellular domain contains a highly conserved region termed the Toll/ interleukin (IL)-1 receptor (TIR) domain (6). To date, ten human and twelve murine functional TLRs have been identified (6). TLR1, 2, 4, 5 and 6 are localized on the cell membrane, and primarily detect bacterial PAMPs, while TLR3, 7, 8 and 9 and murine TLR11 are localized in endosomes or lysosomes, and mainly sense viral PAMPs (11). In addition, TLRs including TLR4 may recognize corresponding DAMPs (11).

TLRs exist at the plasma membrane as monomers, and TLR dimerization, either homo-dimerization or hetero-dimerization, is required for signaling (12). Ligand binding and TLR dimerization recruits TIR domain-containing adaptors, including myeloid differentiation factor 88 (MyD88), MyD88 adapter-like, TIR-domain-containing adapter-inducing interferon- $\beta$ (TRIF) and TRIF-related adapter molecule, to activate downstream signaling cascades including the inhibitor of nuclear factor- $\kappa \mathrm{B}$ kinase (IKK) and mitogen-activated protein kinase (MAPK) pathways (11). In turn these pathways activate nuclear factor $-\kappa \mathrm{B}(\mathrm{NF}-\kappa \mathrm{B})$ and activator protein-1 (AP-1) transcription factors, respectively, to ultimately upregulate pro-inflammatory cytokines including tumor necrosis factor- $\alpha$ (TNF- $\alpha$ ), IL-1 $\beta$, IL-6 and type I interferons (11).

\section{Relationship between TLRs and lung cancer}

In 1863, Rudolf Virchow identified that leukocytes were present in tumor tissue, and thus he hypothesized that there was a link between inflammation and tumor progression (13). Inflammation is an essential immune response to infection or injury. However, persistent infections within the host induce chronic inflammation (14). Innate immune cells, including macrophages, mast cells, dendritic cells and natural killer cells, may repair tissue damage and eliminate invaded pathogenic microorganisms by releasing cytokines, chemokines, matrix remodeling protease, prostaglandin, growth factors, reactive oxygen species (ROS) and reactive nitrogen species (RNS) (15). These above inflammatory mediators are also able to induce genetic and epigenetic changes, such as point mutations in tumor suppressor genes, DNA methylation and post-translational modifications, leading to changes in certain critical pathways required to maintain normal cellular homeostasis, which ultimately leads to the development and progression of cancer (14-17). At present, approximately $18 \%$ of cancer cases are caused by infection and chronic inflammation worldwide, and patients with chronic inflammatory diseases have a higher risk of cancer development $(8,18)$. For instance, the risk of lung cancer in patients with asbestosis has been reported to be ten times higher than that in healthy individuals (19).

The expression of TLRs in lung cancer tissues and the interaction between them have been a focus of research in recent years $(9,20)$. TLRs $1-6$ and 9 are expressed in airway epithelial cells (7). TLRs in lung cancer cells principally reside on the cell membrane or in the cytoplasm. For instance, TLR5 was identified to be mainly expressed on the membrane of lung cancer cells, TLR4, 8 and 9 were mainly expressed in cytoplasm of the cells, while TLR7 was mainly expressed around the nucleus (21-24).
Previous studies have demonstrated that the expression of TLR4, 5, 7, 8 and 9 in NSCLC was markedly higher than that in normal lung tissue (7,23-26). Among these, the expression of TLR4 was positively correlated with the differentiation degree, stage and metastasis of lung cancer cells $(23,25)$; high expression of TLR5 was significantly associated with improved prognosis in patients with NSCLC (24); while the expression of TLR7 was markedly associated with resistance to neoadjuvant chemotherapy and poor clinical outcomes (26).

Epigenetics may be one of the mechanisms by which TLR gene expression is regulated. In patients with pulmonary tuberculosis, aberrant methylation of certain $\mathrm{CpG}$ sites in the TLR2 promoter region has been identified, which was possibly associated with downregulation of TLR2 expression (27). TLR2 CpG promoter hypermethylation has also been noted in non-cystic fibrosis bronchial epithelial cells for the epigenetic control of TLR2 expression (28). DNA methylation of TLR2 may also modulate host innate defense mechanisms and confer increased disease susceptibility, indicated in a chronic Porphyromonas gingivalis infection mouse model (29). For TLR3, cis-acting epigenetic control of TLR3 was responsible for impaired transcriptional activation of TLR3 in dendritic cells derived from cord blood when compared with the cells from adults (30). Epigenetic regulation of TLR4 gene expression through histone deacetylation and DNA methylation in intestinal epithelial cells may also be responsible for the maintenance of intestinal homeostasis (31). Furthermore, it has been noted that epigenetic modification of TLR4 was mediated by methyl-CpG-binding domain protein 2 and specificity protein 1 in gastric cancer (32). Regulation of TLRs or TLR signaling pathways by small noncoding RNAs is also a focus of epigenetic research. MicroRNA-21 (miRNA/miR-21), an oncomiR, may establish an important link between cancer and inflammation, as its upregulation has been reported in numerous cancers $(33,34)$ as well as a number of inflamed states, including in allergic airway inflammation (35) and inflamed lung tissue in lipopolysaccharide (LPS)-treated mice (36). Indeed, Sheedy et al (37) reported that miR-21 was a negative regulator of TLR4 signaling through targeting of tumor suppressor programmed cell death 4 . In addition to miR-21, the cellular miRNA, let-7i, has been observed to regulate TLR4 expression and contribute to cholangiocyte immune responses against Cryptosporidium parvum infection (38). In turn, TLRs are also involved in the epigenetic regulation of lung cancer progression. For example, TLR4 activation promoted the expression of the $\mathrm{H} 3 \mathrm{~K} 9 \mathrm{me} 1 / 2$ demethylase KDM3A, with KDM3A then binding directly to the forkhead box P3 (Foxp3) promoter and promoting its transcription, thereby inducing the secretion of Foxp3-associated downstream inhibitory cytokines (TGF- $\beta 1$, IL-35 and HO-1) and ultimately facilitating the immune system evasion of lung adenocarcinoma (39).

TLRs as receptors on immune cells involved in lung cancer progression have been previously reviewed in detail $(7,8)$, thus the present review only recounts TLRs as sensors on lung cancer cells that function in the processes of cell growth, invasion, angiogenesis and CSC behavior.

TLRs are related to the growth of lung cancer cells. Unlimited proliferation capacity and anti-apoptotic mechanisms are hallmarks of cancer cells $(40,41)$. TLRs may promote the growth 
of lung cancer cells through proliferative or anti-apoptotic signals (Table I).

TLR4 is among the most characterized TLRs that have been identified to be related to the growth of lung cancer cells. TLR4 activation by LPS stimulation, a TLR4 ligand, induced a time- and dose-dependent increase in the proli feration of human lung adenocarcinoma cell line A549 (42). This effect of LPS on A549 cells could be reproduced in a mouse model with subcutaneous injection of A549 cells, whereby LPS treatment prior to cell injection enhanced tumor growth in the implanted tumors (42). A knockdown model of TLR4 significantly suppressed cell proliferation and induced apoptosis in A549 cells, and also suppressed tumor growth in vivo. This was potentially mediated by the phosphatidylinositol 3-kinase/protein kinase B (PI3K/AKT) signaling pathway (25). Zhang et al (43) isolated primary human lung cancer cells from fresh tumor tissue and identified a potential role of a TLR4/ROS/miR-21 pathway in aiding LPS-induced outgrowth of lung cancer cells. In addition to LPS stimulation, ligation of TLR4 by high mobility group box-1 (HMGB1) protein, another ligand of TLR4, inhibited apoptosis in Lewis lung cancer cells by upregulating the anti-apoptotic protein B-cell lymphoma 2 (Bcl-2) and downregulting the pro-apoptotic protein $\mathrm{Bcl}-2$-associated $\mathrm{X}$ protein in a timedependent manner, which was attributed to the PI3K/AKT and extracellular regulated protein kinase (ERK)1/2 signaling pathways (44). Notably, TLR4 activation may also induce resistance of human lung cancer cells to apoptosis induced by TNF- $\alpha$ or TNF-related apoptosis-inducing ligand, mediated by the $N F-\kappa B$ signaling pathway (45). Further experiments have suggested that TLR4 on lung cancer cells mediates resistance of the cells to death induced by cytotoxic T lymphocytes, and promotes tumor growth in vivo (46). TLRs other than TLR4 have also been implicated in tumor growth. For instance, ligation of TLR2 followed by auto- or paracrine signaling by endogenously synthesized IL-8 was involved in lipoteichoic acid-induced proliferation of the NSCLC cell lines A549 and H226 (47). TLR7 or TLR8 ligations in lung cancer cells resulted in activation of $\mathrm{NF}-\kappa \mathrm{B}$ and upregulation of $\mathrm{Bcl}-2$ expression, which were associated with increased cell survival and resistance to apoptosis (21). Accordingly, TLR7 stimulation has been identified to favor the growth of A549 cells in non-obese diabetic/severe combined immunodeficient mice and induce resistance to chemotherapy (26). Similarly, TLR9 agonist $\mathrm{CpG}$ oligonucleotides (CpG-ODNs) could markedly stimulate cell cycle entry and increase the proliferation of human lung cancer cell line 95D, which was accompanied by the selective upregulation of cyclin-dependent kinase 2 , which was critical for cell cycle progression (48). However, the converse effect of TLRs has also been reported. For instance, inhibition of TLR5/MyD88/NF- $\kappa \mathrm{B}$ signaling enhanced tumor growth in mouse xenografts of A549 lung cancer cells in vivo, whereas activation of the TLR5 signaling pathway inhibited the growth (49). Therefore, enhancing the survival pathways and alleviating the apoptotic pathways mediated by TLRs may favor the growth of lung cancer cells.

TLRs are involved in angiogenesis in lung cancer. The formation and development of vascular networks are strictly controlled processes that have both physiological and pathophysiological significance. The formation and development of cancer depends on the growth of a capillary vessel network, as this ensures a supply of oxygen and nutrition to the tumor tissue (50). TLRs, particularly TLR4 and 9, have been identified to be associated with tumor angiogenesis (Table I). In recent years, the vascular endothelial growth factor (VEGF) pathway has gained improved understanding regarding its role in angiogenesis (51). In particular, a study identified that activation of the TLR4/NF- $\kappa \mathrm{B}$ signaling pathway enhanced the expression of VEGF, while inhibition of the pathway disrupted endothelial tube arrangement, blood capillary formation, endothelial sprouting and thus vascular growth $(52,53)$. This was also confirmed in a mouse model, whereby intraperitoneal injection of LPS increased angiogenesis in BALB/c mice bearing 4T1 lung metastases, due to the increased vascular permeability (54). In addition, TLR4 ligation in human lung cancer cells promoted production of the proangiogenic chemokine IL-8 through the p38 MAPK signaling pathway, which served a positive role in the regulation of vessel formation (45). In addition to TLR4, TLR9 has been implicated in the angiogenic process, although its role is controversial. One study identified that TLR9 agonist CpG-ODNs significantly enhanced the secretion of IL-10, an important factor in tumor angiogenesis, in 95D cells $(55,56)$. By contrast, another study observed that TLR9 agonist immunomodulatory oligonucleotides inhibited micro-vessel formation and tumor growth synergistically with epidermal growth factor receptor inhibitors in NSCLC (57). Thus, the exact role of TLR9 in angiogenesis requires further investigation.

TLRs are associated with the invasion of lung cancer cells. Metastasis is the spread of cancer cells from a primary site to a secondary site via the blood or lymphatic system. Metastasis of lung cancer is a malignant marker and a primary reason for poor patient prognosis and in some cases mortality. The five-year survival rate in early-stage NSCLC is $50-70 \%$, though drops to $2-5 \%$ for patients with cancer that has spread distally (2). As aforementioned, vessel formation is conducive to the invasion of lung cancer cells. In addition, TLRs may promote the invasion of lung cancer cells by other mechanisms (Table I). A previous study indicated that TLR3 and TLR4 stimulated respectively by polyinosinic-polycytidylic acid and LPS promoted the autophagy of lung cancer cells, mediated by the adapter protein TRIF, which in turn generated a series of corresponding cytokines, including IL-6, monocyte chemotactic protein 1 , macrophage inflammatory protein3- $\alpha$ and matrix metalloprotein-2 (MMP-2), resulting in migration and invasion of the lung cancer cells (58). TLR4 activation with heat-inactivated Escherichia coli (E. coli) increased gross hepatic metastases of H59 cells (a Lewis lung adenocarcinoma subline) in vivo, and induced $\mathrm{H} 59$ cell migration in vitro; however, when the p38 MAPK or ERK1/2 signaling pathway was inhibited, the adhesion of H59 cells to the extracellular matrix decreased, thus causing a decrease in the migratory ability of the lung cancer cells (59). A similar result was obtained in mouse Lewis lung cancer cells, with the migratory ability of cells significantly increased following LPS stimulation (60). Furthermore, activation of TLR4 by HMGB1 has been reported to induce migration and invasion of A549 and H838 lung cancer cells by activating integrin $\alpha v \beta 3 /$ focal adhesion kinase through the TLR4/NF- $\kappa \mathrm{B}$ pathway (61). Conversely, knockdown of 
Table I. Roles of TLRs in lung cancer progression.

\begin{tabular}{|c|c|c|c|c|}
\hline $\begin{array}{l}\text { TLR } \\
\text { activated }\end{array}$ & Models & $\begin{array}{c}\text { Effect on lung } \\
\text { cancer progression }\end{array}$ & $\begin{array}{c}\text { Pathways or molecules } \\
\text { involved }\end{array}$ & (Refs.) \\
\hline TLR4 & $\begin{array}{c}\text { A549, } \\
\text { Mouse model }\end{array}$ & Favor proliferation & PI3K/AKT & $(25,42)$ \\
\hline TLR4 & $\begin{array}{l}\text { Primary human } \\
\text { lung cancer cells }\end{array}$ & Favor proliferation & ROS/miR-21 & $(43)$ \\
\hline TLR4 & Lewis lung cancer cells & Favor apoptosis & $\begin{array}{c}\text { Bax, Bcl-2, } \\
\text { PI3K/AKT, ERK1/2 }\end{array}$ & (44) \\
\hline TLR4 & $\begin{array}{l}\text { A549, } \\
\text { H1299 }\end{array}$ & Favor apoptosis & $\mathrm{NF}-\kappa \mathrm{B}$ & $(45)$ \\
\hline TLR2 & $\begin{array}{l}\text { A549, } \\
\text { H226 }\end{array}$ & Favor proliferation & IL-8 & $(47)$ \\
\hline TLR7/8 & $\begin{array}{c}\text { A549, } \\
\text { SK-MES, } \\
\text { H1355 }\end{array}$ & Favor cell survival & $\mathrm{NF}-\kappa \mathrm{B}, \mathrm{Bcl}-2$ & $(21)$ \\
\hline TLR7 & A549 & $\begin{array}{l}\text { Favor growth and induce } \\
\text { resistance to chemotherapy }\end{array}$ & l & (26) \\
\hline TLR9 & $95 \mathrm{D}$ & Favor proliferation & CDK2 & $(48)$ \\
\hline TLR5 & A549 & Inhibit growth & $\mathrm{NF}-\kappa \mathrm{B}$ & $(49)$ \\
\hline TLR4 & Mouse model & Favor angiogenesis & VEGF & $(54)$ \\
\hline TLR4 & $\begin{array}{l}\text { A549, } \\
\text { H1299 }\end{array}$ & Favor angiogenesis & p38 MAPK & $(45)$ \\
\hline TLR9 & $95 \mathrm{D}$ & Favor angiogenesis & IL-10 & $(55,56)$ \\
\hline TLR3/4 & $\begin{array}{l}\text { A549, } \\
\text { H460 }\end{array}$ & $\begin{array}{l}\text { Favor migration } \\
\text { and invasion }\end{array}$ & TRIF & $(58)$ \\
\hline TLR4 & H59 & Favor migration & $\begin{array}{l}\text { p38 MAPK, } \\
\text { ERK1/2 }\end{array}$ & $(59)$ \\
\hline TLR4 & $\begin{array}{l}\text { Lewis lung } \\
\text { cancer cells }\end{array}$ & Favor migration & $\begin{array}{l}\text { TGF- } \beta 1, \\
\text { IL-10 }\end{array}$ & $(60)$ \\
\hline TLR4 & $\begin{array}{l}\text { A549, } \\
\text { H838 }\end{array}$ & $\begin{array}{l}\text { Favor migration } \\
\text { and invasion }\end{array}$ & Integrin $\alpha v \beta 3 / \mathrm{FAK}$ & $(61,25)$ \\
\hline TLR9 & 95D, & Favor invasion & MMP-2 & $(62)$ \\
\hline TLR9 & $\begin{array}{c}\mathrm{H} 460, \\
95 \mathrm{D} \\
95 \mathrm{C}\end{array}$ & $\begin{array}{l}\text { Favor growth } \\
\text { and metastasis }\end{array}$ & PI3K/AKT & $(63,64)$ \\
\hline TLR3 & SUM190 & Favor stemness & $\begin{array}{l}\beta \text {-catenin } \\
\mathrm{NF}-\kappa \mathrm{B}\end{array}$ & (71) \\
\hline TLR4 & MCF-7, T47D & Favor stemness & $\begin{array}{c}\text { POU5F1 } \\
\text { SOX2 } \\
\text { NANOG }\end{array}$ & (72) \\
\hline TLR7 & $\begin{array}{l}\text { HCCLM3, } \\
\text { MHCC97-H }\end{array}$ & $\begin{array}{l}\text { Decrease stem cell } \\
\text { no. }\end{array}$ & $\mathrm{IKK} / \mathrm{NF}-\kappa \mathrm{B}$ & (73) \\
\hline TLR4/9 & $\begin{array}{c}\text { Caco-2, HT29, } \\
\text { HCT116 }\end{array}$ & Favor stemness & Nod1/Rip2 & (74) \\
\hline TLR4 & $\begin{array}{l}\text { Mouse model, } \\
\text { human specimen }\end{array}$ & $\begin{array}{c}\text { Decrease CSC } \\
\text { self-renewal }\end{array}$ & RBBP5 & (75) \\
\hline
\end{tabular}

TLR, toll-like receptor; PI3K, phosphatidylinositol 3-kinase; AKT, protein kinase B; ROS, reactive oxygen species; miR, microRNA; Bcl-2, B-cell lymphoma 2 protein; Bax, Bcl-2-associated X protein; ERK, extracellular signal-regulated protein kinase; NF- $\kappa \mathrm{B}$, nuclear factor- $\kappa \mathrm{B}$; IL, interleukin; CDK2, cyclin-dependant kinase 2; p38 MAPK, p38 mitogen-activated protein kinase; TRIF, toll/ IL-1 receptor-domain-containing adapter-inducing interferon- $\beta$; TGF, tumor growth factor; FAK, focal adhesion kinase; MMP, matrix metalloprotein; POU5F1, POU domain, class 5, transcription factor 1; SOX2, sex determining region Y-related HMG box2; Nod1/Rip2, nucleotide-binding oligomerization domaincontaining protein 1 / receptor-interacting protein 2 ; RBBP5, retinoblastoma binding protein 5. 
TLR4 in A549 cells significantly suppressed cell migration and invasion (25). In addition, stimulation of lung cancer 95D cells with TLR9 ligand significantly elevated secretion of IL- $1 \alpha$ and IL-8, as well as the expression of C-X-C chemokine receptor type 4, intercellular cell adhesion molecule-1 and MMP-2, which ultimately contributed to the invasion of the 95D cells; however, the invasive ability of the 95D cells was suppressed by an inhibitor of TLR9 ligand (62). Consistent with these findings, in vivo studies have also demonstrated a direct positive effect of TLR9 signaling on lung cancer metastasis, which was conferred by the PI3K/AKT pathway $(63,64)$.

TLRs are associated with CSC behavior. CSCs make up a small population of cancer cells, and possess self-renewal and differentiation abilities that promote malignancy and, ultimately, treatment resistance and cancer relapse $(65,66)$. Chronic inflammation has been identified as one of the major factors involved in CSC expansion and tumor progression (67). CSCs constitutively exhibit higher NF- $\kappa \mathrm{B}$ activation, which increases stemness in cancer cells (68-70). The activation of $\mathrm{NF}-\kappa \mathrm{B}$ has been attributed to ligation of the TLR signaling pathway (Table I). For instance, TLR3 has been identified to promote a phenotypic switch in breast cancer cells towards a CSC phenotype, which induced tumor growth (71). Further experiments have observed that simultaneous activation of $\beta$-catenin and NF- $\kappa B$ signaling pathways triggered by TLR3 stimulation was required for enhanced CSC phenotypes (71). For TLR4, it has been reported that HMGB1 released by autophagic cancer-associated fibroblasts in the breast cancer microenvironment activated TLR4 on luminal breast cancer cells to facilitate the expansion of breast CSCs and the maintenance of their stemness (72). Contrasting with the tumorigenic role, TLR7 activation with the agonist imiquimod exhibited inhibitory effects on cell proliferation and mammosphere formation in hepatic cells and stem cells, and decreased stem cell number. These effects were achieved through the TLR7/ IKK/NF- $\mathrm{KB} / \mathrm{IL}-6$ signaling pathway (73). Commensal E. coli has been identified as a major protagonist of microbe-induced colorectal oncogenesis (74). In a previous study, repression of the microbe sensing pathway TLR/MyD88 with simultaneous activation of the nucleotide-binding oligomerization domain-containing protein 1 / receptor-interacting protein 2 (Nod1/Rip2) pathway was responsible for the acquisition of stem-like properties in bacteria-infected intestinal cancer cells, which resulted in expansion of a tumorigenic CSC population marked by enhanced malignancy traits, long term self-renewal capacity and robust tumorigenic ability (74). Similarly, Alvarado et al (75) reported that glioblastoma CSCs downregulated TLR4 to evade immune suppression, and that activation of downstream TLR signaling pathways may reduce tumor growth and disrupt CSC self-renewal by repressing the expression of the transcription factor retinoblastoma binding protein 5 (RBBP5) (76).

\section{Conclusion}

The roles of TLRs in immunity have been widely studied. Based on current findings, TLRs as sensors on lung cancer cells may favor the cell growth, angiogenesis and invasive abilities of lung cancer cells and regulate the behavior of CSCs, as detailed in Table I. However, their roles and fundamental mechanisms in lung cancer progression need to be further elucidated. The development of novel treatments that target the TLR pathways may be promising therapeutic strategies for alleviating lung cancer progression. To date, a number of TLR agonists have been approved or are in clinical trials as cancer therapeutics. For instance, Bacillus CalmetteGuérin (BCG), an agonist of TLR2 and 4, has been approved for the treatment of superficial bladder cancer (77); TLR4 agonist monophosphoryl lipid A has been approved for use in the Cervarix vaccine as an adjuvant for the prophylaxis of human papillomavirus-associated cervical cancer (78); and TLR7 agonist imiquimod has been approved as a therapeutic for superficial basal cell carcinoma (79). Although TLRs agonists are promising therapeutics for certain types of cancer, combining the TLR agonist with the current treatments, including radiation and chemotherapy, may be of greater benefit, given that they can exert potent immunostimulatory effects in vivo (80). For instance, the TLR9 agonist CpG-ODN plus chemotherapy is currently under phase III trials for NSCLC and under phase I trials for colorectal cancer (80); and BCG combined with FDA-approved immunostimulatory monoclonal antibody ipilimumab is under phase I trials for melanoma (81). Thus, identification of compatible TLR agonists may be a promising direction for drug development in the future.

\section{Acknowledgements}

The present study was supported by the Natural Science Foundation of Zhejiang Province (grant nos. LY15H160068 and LY18H160060), the National Natural Science Foundation of China (grant nos. 31200581 and 41401517), the Science and Technology Planning Project of Zhejiang Province (grant no. 2015C33223) and the Undergraduate Innovation and Entrepreneurship Training Program of China (grant nos. 201510346008 and 201610346029).

\section{References}

1. Torre LA, Bray F, Siegel RL, Ferlay J, Lortet-Tieulent J and Jemal A: Global cancer statistics, 2012. CA Cancer J Clin 65: 87-108, 2015.

2. Lemjabbar-Alaoui H, Hassan OU, Yang YW and Buchanan P: Lung cancer: Biology and treatment options. Biochim Biophys Acta 1856: 189-210, 2015.

3. Ferlay J, Soerjomataram I, Dikshit R, Eser S, Mathers C, Rebelo M, Parkin DM, Forman D and Bray F: Cancer incidence and mortality worldwide: Sources, methods and major patterns in GLOBOCAN 2012. Int J Cancer 136: E359-E386, 2015.

4. Hirsch FR, Scagliotti GV, Mulshine JL, Kwon R, Curran WJ Jr, Wu YL and Paz-Ares L: Lung cancer: Current therapies and new targeted treatments. Lancet 389: 299-311, 2017.

5. Coussens LM and Werb Z: Inflammation and cancer. Nature 420: 860-867, 2002.

6. Broz P and Monack DM: Newly described pattern recognition receptors team up against intracellular pathogens. Nat Rev Immunol 13: 551-565, 2013

7. Pinto A, Morello S and Sorrentino R: Lung cancer and Toll-like receptors. Cancer Immunol Immunother 60: 1211-1220, 2011

8. Pradere JP, Dapito DH and Schwabe RF: The Yin and Yang of Toll-like receptors in cancer. Oncogene 33: 3485-3495, 2014.

9. Yang LS, Wu WS, Zhang F, Jiang Y, Fan Y, Fang HX and Long J: Role of toll-like receptors in lung cancer. J Recept Signal Transduct Res 34: 342-344, 2014. 
10. Rakoff-Nahoum S and Medzhitov R: Toll-like receptors and cancer. Nat Rev Cancer 9: 57-63, 2009.

11. Kay E, Scotland RS and Whiteford JR: Toll-like receptors: Role in inflammation and therapeutic potential. Biofactors 40 : 284-294, 2014

12. Kawai T and Akira S: The role of pattern-recognition receptors in innate immunity: Update on Toll-like receptors. Nat Immunol 11: 373-384, 2010.

13. Balkwill $\mathrm{F}$ and Mantovani A: Inflammation and cancer: Back to Virchow? Lancet 357: 539-545, 2001.

14. Keibel A, Singh V and Sharma MC: Inflammation, microenvironment, and the immune system in cancer progression. Curr Pharm Des 15: 1949-1955, 2009.

15. Hussain SP and Harris CC: Inflammation and cancer: An ancient link with novel potentials. Int J Cancer 121: 2373-2380, 2007

16. Yasmin R, Siraj S, Hassan A, Khan AR, Abbasi R and Ahmad N Epigenetic regulation of inflammatory cytokines and associated genes in human malignancies. Mediators Inflamm 2015: 201703 , 2015.

17. Payen VL, Porporato PE, Baselet B and Sonveaux P: Metabolic changes associated with tumor metastasis, part 1: Tumor $\mathrm{pH}$, glycolysis and the pentose phosphate pathway. Cell Mol Life Sci 73: 1333-1348, 2016.

18. Bartsch $\mathrm{H}$ and Nair J: Chronic inflammation and oxidative stress in the genesis and perpetuation of cancer: Role of lipid peroxidation, DNA damage, and repair. Langenbecks Arch Surg 391: 499-510, 2006

19. Ameille J, Brochard P, Letourneux M, Paris C and Pairon JC: Asbestos-related cancer risk in patients with asbestosis or pleural plaques. Rev Mal Respir 28: e11-e17, 2011.

20. Łagiedo M, Sikora J and Kaczmarek M: Damage-associated molecular patterns in the course of lung cancer - A review. Scand J Immunol 82: 95-101, 2015.

21. Cherfils-Vicini J, Platonova S, Gillard M, Laurans L, Validire P, Caliandro R, Magdeleinat P, Mami-Chouaib F, Dieu-Nosjean MC, Fridman WH, et al: Triggering of TLR7 and TLR8 expressed by human lung cancer cells induces cell survival and chemoresistance. J Clin Invest 120: 1285-1297, 2010.

22. Droemann D, Albrecht D, Gerdes J, Ulmer AJ, Branscheid D, Vollmer E, Dalhoff K, Zabel P and Goldmann T: Human lung cancer cells express functionally active Toll-like receptor 9. Respir Res 6: 1, 2005

23. Zhang YB, He FL, Fang M, Hua TF, Hu BD, Zhang ZH, Cao Q and Liu RY: Increased expression of Toll-like receptors 4 and 9 in human lung cancer. Mol Biol Rep 36: 1475-1481, 2009.

24. Zhou H, Chen JH, Hu J, Luo YZ, Li F, Xiao L and Zhong MZ: High expression of Toll-like receptor 5 correlates with better prognosis in non-small-cell lung cancer: An anti-tumor effect of TLR5 signaling in non-small cell lung cancer. J Cancer Res Clin Oncol 140: 633-643, 2014.

25. Li D, Jin Y, Sun Y, Lei J and Liu C: Knockdown of toll-like receptor 4 inhibits human NSCLC cancer cell growth and inflammatory cytokine secretion in vitro and in vivo. Int J Oncol 45 813-821, 2014

26. Chatterjee S, Crozet L, Damotte D, Iribarren K, Schramm C, Alifano M, Lupo A, Cherfils-Vicini J, Goc J, Katsahian S, et al: TLR7 promotes tumor progression, chemotherapy resistance, and poor clinical outcomes in non-small cell lung cancer. Cancer Res 74: 5008-5018, 2014.

27. Chen YC, Hsiao CC, Chen CJ, Chao TY, Leung SY, Liu SF, Wang CC, Wang TY, Chang JC, Wu CC, et al: Aberrant Toll-like receptor 2 promoter methylation in blood cells from patients with pulmonary tuberculosis. J Infect 69: 546-557, 2014.

28. Shuto T, Furuta T, Oba M, Xu H, Li JD, Cheung J, Gruenert DC, Uehara A, Suico MA, Okiyoneda T, et al: Promoter hypomethylation of Toll-like receptor-2 gene is associated with increased proinflammatory response toward bacterial peptidoglycan in cystic fibrosis bronchial epithelial cells. FASEB J 20: 782-784, 2006.

29. Benakanakere M, Abdolhosseini M, Hosur K, Finoti LS and Kinane DF: TLR2 promoter hypermethylation creates innate immune dysbiosis. J Dent Res 94: 183-191, 2015.

30. Porrás A, Kozar S, Russanova V, Salpea P, Hirai T, Sammons N, Mittal P, Kim JY, Ozato K, Romero R, et al: Developmental and epigenetic regulation of the human TLR3 gene. Mol Immunol 46 : 27-36, 2008.

31. Takahashi K, Sugi Y, Hosono A and Kaminogawa S: Epigenetic regulation of TLR4 gene expression in intestinal epithelial cells for the maintenance of intestinal homeostasis. J Immunol 183: 6522-6529, 2009.
32. Kim TW, Lee SJ, Oh BM, Lee H, Uhm TG, Min JK, Park YJ, Yoon SR, Kim BY, Kim JW, et al: Epigenetic modification of TLR4 promotes activation of NF- $\kappa B$ by regulating methyl-CpGbinding domain protein 2 and $\mathrm{Sp} 1$ in gastric cancer. Oncotarget 7: 4195-4209, 2016

33. Calin GA and Croce CM: MicroRNA signatures in human cancers. Nat Rev Cancer 6: 857-866, 2006.

34. Cho WC: OncomiRs: The discovery and progress of microRNAs in cancers. Mol Cancer 6: 60, 2007.

35. $\mathrm{Lu}$ TX, Munitz A and Rothenberg ME: MicroRNA-21 is up-regulated in allergic airway inflammation and regulates IL-12p35 expression. J Immunol 182: 4994-5002, 2009.

36. Moschos SA, Williams AE, Perry MM, Birrell MA, Belvisi MG and Lindsay MA: Expression profiling in vivo demonstrates rapid changes in lung microRNA levels following lipopolysaccharideinduced inflammation but not in the anti-inflammatory action of glucocorticoids. BMC Genomics 8: 240, 2007.

37. Sheedy FJ, Palsson-McDermott E, Hennessy EJ, Martin C, O'Leary JJ, Ruan Q, Johnson DS, Chen Y and O'Neill LA: Negative regulation of TLR4 via targeting of the proinflammatory tumor suppressor PDCD4 by the microRNA miR-21. Nat Immunol 11: 141-147, 2010.

38. Chen XM, Splinter PL, O'Hara SP and LaRusso NF: A cellular micro-RNA, let-7i, regulates Toll-like receptor 4 expression and contributes to cholangiocyte immune responses against Cryptosporidium parvum infection. J Biol Chem 282: 28929-28938, 2007

39. Li Y, Yang W, Wu B, Liu Y, Li D, Guo Y, Fu H and Li Y: KDM3A promotes inhibitory cytokines secretion by participating in TLR4 regulation of Foxp3 transcription in lung adenocarcinoma cells. Oncol Lett 13: 3529-3537, 2017

40. Cotter TG: Apoptosis and cancer: The genesis of a research field. Nat Rev Cancer 9: 501-507, 2009.

41. Hanahan D and Weinberg RA: Hallmarks of cancer: The next generation. Cell 144: 646-674, 2011.

42. Hattar K, Savai R, Subtil FS, Wilhelm J, Schmall A, Lang DS, Goldmann T, Eul B, Dahlem G, Fink L, et al: Endotoxin induces proliferation of NSCLC in vitro and in vivo: Role of COX-2 and EGFR activation. Cancer Immunol Immunother 62: 309-320, 2013.

43. Zhang X, Wang C, Shan S, Liu X, Jiang Z and Ren T: TLR4/ ROS/miRNA-21 pathway underlies lipopolysaccharide instructed primary tumor outgrowth in lung cancer patients. Oncotarget 7: 42172-42182, 2016

44. Xu X, Zhu H, Wang T, Sun Y, Ni P, Liu Y, Tian S, Amoah Barnie P, Shen $\mathrm{H}, \mathrm{Xu} \mathrm{W}$, et al: Exogenous high-mobility group box 1 inhibits apoptosis and promotes the proliferation of lewis cells via RAGE/TLR4-dependent signal pathways. Scand J Immunol 79: 386-394, 2014

45. He W, Liu Q, Wang L, Chen W, Li N and Cao X: TLR4 signaling promotes immune escape of human lung cancer cells by inducing immunosuppressive cytokines and apoptosis resistance. Mol Immunol 44: 2850-2859, 2007.

46. Huang B, Zhao J, Li H, He KL, Chen Y, Chen SH, Mayer L, Unkeless JC and Xiong H: Toll-like receptors on tumor cells facilitate evasion of immune surveillance. Cancer Res 65: 5009-5014, 2005

47. Hattar K, Reinert CP, Sibelius U, Gökyildirim MY, Subtil FSB Wilhelm J, Eul B, Dahlem G, Grimminger F, Seeger W, et al: Lipoteichoic acids from Staphylococcus aureus stimulate proliferation of human non-small-cell lung cancer cells in vitro. Cancer Immunol Immunother 66: 799-809, 2017.

48. Xu L, Wang C, Wen Z, Yao X, Liu Z, Li Q, Wu Z, Xu Z, Liang Y and Ren T: Selective up-regulation of CDK2 is critical for TLR9 signaling stimulated proliferation of human lung cancer cell. Immunol Lett 127: 93-99, 2010.

49. Zhou SX, Li FS, Qiao YL, Zhang XQ and Wang ZD: Toll-like receptor 5 agonist inhibition of growth of A549 lung cancer cells in vivo in a Myd88 dependent manner. Asian Pac J Cancer Prev 13: 2807-2812, 2012.

50. Pandya NM, Dhalla NS and Santani DD: Angiogenesis - a new target for future therapy. Vascul Pharmacol 44: 265-274, 2006.

51. Zhao Y and Adjei AA: Targeting angiogenesis in cancer therapy: Moving beyond vascular endothelial growth factor. Oncologist 20: 660-673, 2015.

52. Dey G, Bharti R, Ojha PK, Pal I, Rajesh Y, Banerjee I, Banik P, Parida S, Parekh A, Sen R, et al: Therapeutic implication of 'Iturin A' for targeting MD-2/TLR4 complex to overcome angiogenesis and invasion. Cell Signal 35: 24-36, 2017. 
53. Shin JM, Park JH, Kim HJ, Park IH and Lee HM: Cigarette smoke extract increases vascular endothelial growth factor production via TLR4/ROS/MAPKs/NF-kappaB pathway in nasal fibroblast. Am J Rhinol Allergy 31: 78-84, 2017.

54. Harmey JH, Bucana CD, Lu W, Byrne AM, McDonnell S, Lynch C, Bouchier-Hayes D and Dong Z: Lipopolysaccharideinduced metastatic growth is associated with increased angiogenesis, vascular permeability and tumor cell invasion. Int J Cancer 101: 415-422, 2002.

55. Ren T, Xu L, Jiao S, Wang Y, Cai Y, Liang Y, Zhou Y, Zhou H and Wen Z: TLR9 signaling promotes tumor progression of human lung cancer cell in vivo. Pathol Oncol Res 15: 623-630, 2009.

56. Hatanaka H, Abe Y, Naruke M, Tokunaga T, Oshika Y Kawakami T, Osada H, Nagata J, Kamochi J, Tsuchida T, et al: Significant correlation between interleukin 10 expression and vascularization through angiopoietin/TIE2 networks in non-small cell lung cancer. Clin Cancer Res 7: 1287-1292, 2001.

57. Damiano V, Caputo R, Bianco R, D'Armiento FP, Leonardi A De Placido S, Bianco AR, Agrawal S, Ciardiello F and Tortora G: Novel toll-like receptor 9 agonist induces epidermal growth factor receptor (EGFR) inhibition and synergistic antitumor activity with EGFR inhibitors. Clin Cancer Res 12: 577-583, 2006

58. Zhan Z, Xie X, Cao H, Zhou X, Zhang XD, Fan H and Liu Z: Autophagy facilitates TLR4- and TLR3-triggered migration and invasion of lung cancer cells through the promotion of TRAF6 ubiquitination. Autophagy 10: 257-268, 2014.

59. Chow SC, Gowing SD, Cools-Lartigue JJ, Chen CB, Berube J, Yoon HW, Chan CH, Rousseau MC, Bourdeau F, Giannias B et al: Gram negative bacteria increase non-small cell lung cancer metastasis via Toll-like receptor 4 activation and mitogenactivated protein kinase phosphorylation. Int J Cancer 136 : $1341-1350,2015$

60. Li C, Li H, Jiang K, Li J and Gai X: TLR4 signaling pathway in mouse Lewis lung cancer cells promotes the expression of TGF- $\beta 1$ and IL-10 and tumor cells migration. Biomed Mater Eng 24: 869-875, 2014.

61. Zhu J, Luo J, Li Y, Jia M, Wang Y, Huang Y and Ke S: HMGB1 induces human non-small cell lung cancer cell motility by activating integrin $\alpha v \beta 3 / \mathrm{FAK}$ through TLR4/NF- $\kappa \mathrm{B}$ signaling pathway. Biochem Biophys Res Commun 480: 522-527, 2016.

62. Ren T, Wen ZK, Liu ZM, Liang YJ, Guo ZL and Xu L: Functional expression of TLR9 is associated to the metastatic potential of human lung cancer cell: Functional active role of TLR9 on tumor metastasis. Cancer Biol Ther 6: 1704-1709, 2007.

63. Jiang DS, Wang YW, Jiang J, Li SM, Liang SZ and Fang HY: MicroRNA-26a involved in Toll-like receptor 9 mediated lung cancer growth and migration. Int J Mol Med 34: 307-312, 2014.

64. Xu L, Wen Z, Zhou Y, Liu Z, Li Q, Fei G, Luo J and Ren T: MicroRNA-7-regulated TLR9 signaling-enhanced growth and metastatic potential of human lung cancer cells by altering the phosphoinositide-3-kinase, regulatory subunit 3/Akt pathway. Mol Biol Cell 24: 42-55, 2013.

65. Magee JA, Piskounova E and Morrison SJ: Cancer stem cells: Impact, heterogeneity, and uncertainty. Cancer Cell 21: 283-296, 2012.

66. Visvader JE and Lindeman GJ: Cancer stem cells in solid tumours: Accumulating evidence and unresolved questions. Nat Rev Cancer 8: 755-768, 2008.

67. Yeh DW, Huang LR, Chen YW, Huang CF and Chuang TH: Interplay between inflammation and stemness in cancer cells: The role of Toll-like receptor signaling. J Immunol Res 2016 : 4368101,2016
68. Birnie R, Bryce SD, Roome C, Dussupt V, Droop A, Lang SH, Berry PA, Hyde CF, Lewis JL, Stower MJ, et al: Gene expression profiling of human prostate cancer stem cells reveals a pro-inflammatory phenotype and the importance of extracellular matrix interactions. Genome Biol 9: R83, 2008.

69. Garner JM, Fan M, Yang CH, Du Z, Sims M, Davidoff AM and Pfeffer LM: Constitutive activation of signal transducer and activator of transcription 3 (STAT3) and nuclear factor $\kappa \mathrm{B}$ signaling in glioblastoma cancer stem cells regulates the Notch pathway. J Biol Chem 288: 26167-26176, 2013.

70. Rajasekhar VK, Studer L, Gerald W, Socci ND and Scher HI: Tumour-initiating stem-like cells in human prostate cancer exhibit increased NF- $\kappa$ B signalling. Nat Commun 2: 162, 2011.

71. Jia D, Yang W, Li L, Liu H, Tan Y, Ooi S, Chi L, Filion LG, Figeys D and Wang L: $\beta$-Catenin and NF- $\kappa \mathrm{B}$ co-activation triggered by TLR3 stimulation facilitates stem cell-like phenotypes in breast cancer. Cell Death Differ 22: 298-310, 2015.

72. Zhao XL, Lin Y, Jiang J, Tang Z, Yang S, Lu L, Liang Y, Liu X, Tan J, Hu XG, et al: High-mobility group box 1 released by autophagic cancer-associated fibroblasts maintains the stemness of luminal breast cancer cells. J Pathol 243: 376-389, 2017.

73. Ren X, Wang F, Ji B and Gao C: TLR7 agonist induced repression of hepatocellular carcinoma via the TLR7-IKK-NF-кB-IL6 signaling pathway. Oncol Lett 11: 2965-2970, 2016.

74. Sahu U, Choudhury A, Parvez S, Biswas S and Kar S: Induction of intestinal stemness and tumorigenicity by aberrant internalization of commensal non-pathogenic E. coli. Cell Death Dis 8: e2667, 2017.

75. Alvarado AG, Thiagarajan PS, Mulkearns-Hubert EE, Silver DJ, Hale JS, Alban TJ, Turaga SM, Jarrar A, Reizes O, Longworth MS, et al: Glioblastoma cancer stem cells evade innate immune suppression of self-renewal through reduced TLR4 expression. Cell stem cell 20: 450-461, 2017.

76. Finocchiaro G: TLRgeting evasion of immune pathways in glioblastoma. Cell Stem Cell 20: 422-424, 2017.

77. Herr HW and Morales A: History of bacillus Calmette-Guerin and bladder cancer: An immunotherapy success story. J Urol 179: 53-56, 2008.

78. Paavonen J, Naud P, Salmerón J, Wheeler CM, Chow SN, Apter D, Kitchener H, Castellsague X, Teixeira JC, Skinner SR, et al; HPV PATRICIA Study Group: Efficacy of human papillomavirus (HPV)-16/18 AS04-adjuvanted vaccine against cervical infection and precancer caused by oncogenic HPV types (PATRICIA): Final analysis of a double-blind, randomised study in young women. Lancet 374: 301-314, 2009.

79. Chang YC, Madkan V, Cook-Norris R, Sra K and Tyring S: Current and potential uses of imiquimod. South Med J 98: 914-920, 2005.

80. Kanzler H, Barrat FJ, Hessel EM and Coffman RL: Therapeutic targeting of innate immunity with Toll-like receptor agonists and antagonists. Nat Med 13: 552-559, 2007.

81. Vacchelli E, Eggermont A, Sautès-Fridman C, Galon J, Zitvogel L, Kroemer G and Galluzzi L: Trial Watch: Toll-like receptor agonists for cancer therapy. OncoImmunology 2: e25238, 2013

This work is licensed under a Creative Commons

Attribution-NonCommercial-NoDerivatives 4.0 International (CC BY-NC-ND 4.0) License. 